\title{
The Effects of Treatment on Serum Hepcidin and Iron Homeostasis in HIV-1-Infected Individuals
}

\author{
Joel da Cunha ${ }^{1,2^{*}}$, Luciana Morganti Ferreira Maselli1,3*, Jovino dos Santos Ferreira ${ }^{4}$, \\ Celso Spada², Sérgio Paulo Bydlowski" ${ }^{1 \#}$ \\ ${ }^{1}$ Laboratory of Genetics and Molecular Hematology (LIM31), University of São Paulo School of Medicine \\ (FMUSP), São Paulo, Brazil \\ ${ }^{2}$ Clinical Analysis Department, Health Sciences Center, Federal University of Santa Catarina (UFSC), \\ Florianópolis, Brazil \\ ${ }^{3}$ Research Division, Pró-Sangue Hemocentro de São Paulo Foundation, São Paulo, Brazil \\ ${ }^{4}$ Hemotherapy Service of University Hospital, Federal University of Santa Catarina (UFSC), Florianópolis, Brazil \\ Email: ${ }^{\text {spbydlow@usp.br }}$
}

Received 26 March 2015; accepted 23 August 2015; published 26 August 2015

Copyright (C) 2015 by authors and Scientific Research Publishing Inc.

This work is licensed under the Creative Commons Attribution International License (CC BY). http://creativecommons.org/licenses/by/4.0/

(c) (7) Open Access

\section{Abstract}

Background: Hepcidin is the principal regulator of iron absorption and its tissue distribution. Its correlation with iron homeostasis in individuals infected with human immunodeficiency virus type-1 (HIV-1) treated with different regimens of highly active antiretroviral therapy (HAART) was investigated. Methods: Serum hepcidin levels were determined in 448 volunteers. Of these, 372 were HIV-1-infected individuals, and 93 did not receive HAART (ART-naïve) while 279 received HAART consisting of a non-nucleoside reverse transcriptase inhibitor (NNRTI-based) and protease inhibitors (PI-based); both were used in association with a nucleoside reverse transcriptase inhibitor (NRTI). Seventy-six additional HIV-1 seronegative individuals were enrolled in the study. The following parameters were quantified: hematological parameters, iron biomarkers and markers of infection (CD4+ and $\mathrm{CD8}^{+}{ }^{+}$-cells), and HIV-1 RNA (viral load). Results: Serum hepcidin, iron and ferritin levels, as well as the marker of infection, CD4+ ${ }^{+}$-cells, were significantly lower in the ART-naïve group compared with other groups. Additionally, transferrin saturation, iron binding capacity, hemoglobin level and erythrocyte level were not significantly different, and anemia was not observed in the different groups. Conclusions: HIV-1 infection affected serum hepcidin, iron and ferritin levels in the ART-naïve group, and the different HAART regimens restored the levels of hepcidin and iron homeostasis in HIV-1-infected individuals who have unde-

\footnotetext{
*Both authors have equally contributed to this paper.
}

\#Corresponding author. 
tectable HIV-1 RNA levels.

Keywords

Hepcidin, Iron Homeostasis, HIV-1, HAART, ART-Naïve, CD4+ T-Cells

\section{Introduction}

The control of absorption, storage and circulation of iron in the body is regulated by complex mechanisms to maintain an appropriate amount of iron in the circulation and within tissues and avoid deficiency or overload [1]. Hepcidin is a key hormone governing human iron homeostasis [2]. It is a 25-aminoacid protein consisting of 8 cysteine residues and four disulfide bonds and is encoded by the gene HAMP (Hepcidin Anti-microbial Peptide) that produces an 84-amino acid preprohepcidin, which, when cleaved, forms a 60 -amino acid prohepcidin complex that lacks iron-regulatory activity. Then, a new cleavage occurs to form the 25-amino acid hepcidin hormone [3]. Like other peptide hormones, hepcidin is synthesized in hepatocytes; however, other cell types including macrophages and adipocytes also contain hepcidin mRNA, but their local and systemic contributions to the production of bioactive hepcidin has not been well established [4]. Hepcidin function involves regulating the cellular concentration of its receptor ferroportin in hepatocytes. Ferroportin is the only known cellular iron exporter, and it is essential for iron homeostasis [5]. Hepcidin levels in the blood are regulated by different factors, such as the concentration of blood iron, anemia, hypoxia and inflammation [6]. In response to the administration of iron orally or intravenously, large amounts of liver hepcidin are produced by reducing iron absorption through the intestine [7]. In turn, low serum iron concentrations are followed by a reduction in hepcidin production, leading to an increased release of iron from its stores and increased absorption through the intestine [8]. The observed changes in serum hepcidin levels are similar to the changes observed in the levels of ferritin; thus, levels of hepcidin and ferritin decrease in response to low iron stores, increasing the store of iron [9]. The induction of hepcidin in the context of inflammation has an important role related to anemia that is caused by inflammation, also referred to as anemia of chronic disease [10]. Hepcidin is also considered an acute-phase protein induced by interleukin-6 (IL-6) during infection and inflammation processes that decrease circulating iron and iron delivery to cells [11]. In this context, different studies suggest that cellular stores of iron could affect the course and progression of HIV-1 infection in humans. High iron concentrations appear to be associated with increased mortality and viral load of human immunodeficiency virus type-1 (HIV-1), significantly increasing the susceptibility to opportunistic infections and altering the immune response and the degree of immunodeficiency [12]. Xu and colleagues (2010) have suggested that hepcidin and the efflux of ferroportin-mediated iron could affect the regulation of HIV-1 transcription. In this way, the increase in iron stores was associated with a rapid progression of HIV-1 in patients with thalassemia major who received oral iron and in HIV-1-infected individuals who had haptoglobin polymorphisms [13]. Additionally, the survival rate of HIV-1-infected individuals has shown an inverse correlation with high concentrations of iron in bone marrow macrophages [14]. In women with HIV-1 without a diagnosis of anemia, high concentrations of serum ferritin were associated with an increase in HIV-1 RNA (viral load), suggesting that elevated iron stores influence the progression of HIV-1 and that high concentrations of iron predict a high mortality rate in infected adults [12] [15]. However, studies on the changes in serum hepcidin levels and its relation to iron metabolism in HIV-1-infected individuals remain sparse. In this study, we investigated serum hepcidin levels, biomarkers of iron homeostasis, and markers of HIV-1 in a large number of individuals receiving different regimens of highly active antiretroviral therapy (HAART), as well as in individuals without therapy (ART-naïve).

\section{Materials and Methods}

\subsection{Participants and Study Design}

This cross-sectional study was conducted from November 2012 to December 2013 with 448 volunteers (age $\geq$ 18 years). Of these, 372 HIV-1-infected individuals were at the University Hospital of the Federal University of Santa Catarina-HU/UFSC, and the Clinical Hospital-University of São Paulo Medical School-HCFMUSP. Se- 
venty-six additional HIV-1 seronegative individuals from the blood bank at HU/UFSC were also enrolled in the study (Table 1). In the group of HIV-1-infected individuals, 93 were not undergoing the HAART regimen (ART-naïve), and 279 were either using a HAART regimen consisting of a non-nucleoside reverse transcriptase inhibitor (NNRTI-based; $n=151$ ) in association with a nucleoside reverse transcriptase inhibitor (NRTI) or using protease inhibitors (PI-based; $n=128$ ) in association with an NRTI (Table 2). The volunteers were informed of the need for a simple blood collection. The HIV-1-infected group was strictly followed every 90 days in a clinical and laboratorial manner at HU/UFSC, and no opportunistic infections were observed. Individuals were excluded from this study if they were diagnosed with hepatitis or had used an iron-based therapy, recombinant human erythropoietin, or modifiers of iron metabolism and/or had received a blood transfusion, immunosuppressive drugs, or anti-inflammatory steroids or non-steroids in the three months preceding the day of blood collection. Demographic, baseline characteristics and the different antiretroviral therapy regimes of the groups are shown in Table 1 and Table 2.

\subsection{Blood Sample Collection}

Blood samples $(5 \mu \mathrm{L})$ with ethylenediaminetetraacetic acid (EDTA) were obtained by antecubital venous puncture using a vacuum system (Vacutainer ${ }^{\circledR}$, Becton/Dickinson Co., NJ, USA) in the early morning after subjects had fasted for 12 to 14 hours. Serum samples were obtained by centrifuging the blood in a CELM model LS-II centrifuge (CELM Co., SP, BRA) at $2500 \mathrm{rpm}(1050 \times \mathrm{g})$ at $4{ }^{\circ} \mathrm{C}$ for 10 minutes. The samples were then divided into $300 \mu \mathrm{L}$ aliquots, transferred to cryogenic tubes and stored in liquid nitrogen at $-180^{\circ} \mathrm{C}$ until testing.

\subsection{Markers of Infection}

HIV-1 RNA was quantified from plasma using the commercially available Nucleic Acid Sequence Based

Table 1. Baseline characteristics of the study subjects, $n=448$.

\begin{tabular}{cccccc}
\hline & & \multicolumn{4}{c}{ HIV-1-infected individuals $(\mathrm{n}=372)$} \\
\hline Parameters $^{(1)}$ & Seronegative $(\mathrm{n}=76)$ & ART-naïve $(\mathrm{n}=93)$ & NNRTI-based $(\mathrm{n}=151)$ & PI-based $(\mathrm{n}=128)$ & $P$ value ${ }^{(2)}$ \\
\hline Gender $(\mathrm{M} / \mathrm{F})$ & $48 / 28$ & $55 / 38$ & $98 / 53$ & $71 / 57$ & - \\
Age (years) & $36(18,54)$ & $38(18,56)$ & $40(21,57)$ & $41(18,57)$ & $\mathrm{ns}$ \\
BMI $\left(\mathrm{kg} / \mathrm{m}^{2}\right)$ & $21(20,24)$ & $18(16,23)$ & $21(19,32)$ & $22(18,33)$ & $\mathrm{ns}$ \\
\hline
\end{tabular}

Note: NNRTI, non-nucleoside reverse transcriptase inhibitor; PI, protease inhibitor; M, male; F, female; BMI, body mass index [weight/height ${ }^{2}$ $\left(\mathrm{kg} / \mathrm{m}^{2}\right)$ ]; ns, no significant difference. ${ }^{(1)}$ Median [interquartile range (IQR): $2 \%-75 \%$; $95 \%$ confidence interval $\left.(\mathrm{CI})\right]$. ${ }^{(2)} \mathrm{P}$ value: comparison between groups by univariate analysis of variance (ANOVA) for multiple comparisons and Tukey's honest significant difference (HSD) test.

Table 2. Highly active antiretroviral therapy (HAART) regimens of the study groups, $n=279$.

\begin{tabular}{|c|c|}
\hline Antiretroviral therapy, n (\%) $)^{(1)}$ & $(n=279)$ \\
\hline \multicolumn{2}{|l|}{ NNRTI-based, $\mathrm{n}=151$ (54) } \\
\hline Efavirenz (EFV) 600 mg (qd) + zidovudine (AZT) 300 mg + lamivudine (3TC) 150 mg (bid) & $78(52)$ \\
\hline Efavirenz (EFV) 600 mg (qd) + estavudine (d4T) 40 mg + lamivudine (3TC) 150 mg (bid) & $11(7)$ \\
\hline Efavirenz (EFV) 600 mg (qd) + tenofovir (TDF) 300 mg + lamivudine (3TC) 150 mg (bid) & $8(5)$ \\
\hline Nevirapine (NVP) 200 mg (bid) + zidovudine (AZT) 300 mg + lamivudine (3TC) 150 mg (bid) & $28(19)$ \\
\hline Nevirapine (NVP) 200 mg (bid) + estavudine (d4T) 40 mg + lamivudine (3TC) 150 mg (bid) & $15(10)$ \\
\hline Nevirapine (NVP) 200 mg (bid) + tenofovir (TDF) 300 mg + lamivudine (3TC) 150 mg (bid) & $11(7)$ \\
\hline \multicolumn{2}{|l|}{ PI-based, $n=128(46)$} \\
\hline Lopinavir/ritonavir (LOP/r) 400 mg/100 mg (bid) + zidovudine (AZT) 300 mg + lamivudine (3TC) 150 mg (bid) & $60(46)$ \\
\hline Lopinavir/ritonavir (LOP/r) 400 mg/100 mg (bid) + estavudine (d4T) 40 mg + lamivudine (3TC) 150 mg (bid) & $68(54)$ \\
\hline
\end{tabular}

Note: NNRTI, non-nucleoside reverse transcriptase inhibitor; qd, once daily; bid, twice daily; PI, protease inhibitor. ${ }^{(1)}$ Therapy with oral administration. 
Amplification kit (NASBA ${ }^{\circledR}$, Organon Teknika, Boxtel, the Netherlands). The minimum detection limit indicated by the manufacturer is 50 copies/mL of HIV-1 RNA. Subpopulations of $\mathrm{CD} 4^{+} \mathrm{T}$-cells, $\mathrm{CD} 8^{+} \mathrm{T}$-cells, and $\mathrm{CD}^{+} \mathrm{T}$-cells as well as $\mathrm{CD}^{+}: \mathrm{CD}^{+}$and $\mathrm{CD}^{+}: \mathrm{CD}^{+}$cells were quantified by three-color flow cytometry using monoclonal antibodies and a Becton/Dickinson FACS count ${ }^{\circledR}$ flow cytometer (Becton/Dickinson Co., San Jose, CA, USA).

\subsection{Clinical Laboratory Analysis}

The serum hepcidin levels were determined by an enzyme-linked immunosorbent assay (ELISA) kit for hepcidin (ELISA-Hepc ${ }^{\circledR}$; order no. E1979Hu, 96tests) following the manufacturer's instructions (Uscn Life Science Inc., Wuhan, China). Blood in EDTA-containing vacutainers was analyzed using an automatic cell counter, Coulter ${ }^{\circledR}$ LH 750 Hematology Analyzer (Beckman Coulter Inc., CA, USA), to determine the complete blood count, including erythrocytes, hemoglobin, hematocrit, mean corpuscular volume, mean corpuscular hemoglobin, platelet and reticulocytes. Regarding iron metabolism, briefly, we quantified serumiron, ferritin, transferrin saturation and total iron binding capacity (TIBC) using the Siemens Dimension ${ }^{\circledR}$ Clinical Chemistry Systemand Siemens Immulite 2000 system (Siemens Medical Solutions Diagnostics, LA, USA). All of these parameters were measured during routine clinical screening.

\subsection{Statistical Analysis}

The results are expressed as the arithmetic mean plus standard deviation (mean \pm SD) and median [interquartile range (IQR): 95\% confidence interval (CI)]. Calculations to determine whether differences between the various groups were significant were carried out using the non-parametric Kruskal-Wallistest or Student's t-test. We also used univariate analysis of variance (ANOVA) for multiple comparisons followed by Tukey' shonest significant difference (HSD) test. Correlation analysis between parameters was performed using Spearman's test. All descriptive and statistical analyses were performed using the Statistical Package for Social Sciences Software version $12.0^{\circledR}$ (SPSS Inc., Chicago, IL, USA) and SAS ${ }^{\circledR}$ e. Charts were constructed using Graph Pad Prism ${ }^{\circledR}$ version 5.0 (Graph Pad Software Inc., La Jolla, USA). Statistical significance was set at $P<0.05$.

\subsection{Ethical Considerations}

Participants were informed of all procedures in the study, and their consent to participate in the study was confirmed in writing according to the guidelines of the Bioethical Committee. Ethical approval for this study was granted by the ethical committees of the Human Research of Clinical Hospital-University of São Paulo Medical School-HCFMUSP and HU/UFSC, CAAE 07288912.6.0000.0065, number 141.739, November 25, 2012.

\section{Results}

\subsection{Background}

In the study population, the parameters age (years) and body mass index [BMI; weight/height ${ }^{2}\left(\mathrm{~kg} / \mathrm{m}^{2}\right)$ ] were homogeneous, with no differences between the groups of seronegative and HIV-1-infected individuals. In both groups, the number of males was higher than females (Table 1). Table 2 and Table 3 describe the different HAART regimens used and the comparison of the assessments of the laboratory parameters in all of the groups that were evaluated, respectively.

\subsection{Markers of Infection}

The markers of infection by HIV-1, such as $\mathrm{CD} 4^{+} \mathrm{T}$-cells and $\mathrm{CD} 8^{+} \mathrm{T}$-cells, showed suitable means in the treated groups (Table 3). The mean values of $\mathrm{CD} 4^{+} \mathrm{T}$-cells in the treated groups were significantly different in comparison with the ART-naïve group, and the median number of $\mathrm{CD}^{+}$T-cells was not significantly different (Table 3). HIV-1 RNA was undetectable, $<50$ copies/mL, in all subjects in the NNRTI-based group and PI-based group. The ART-naïve group had elevated levels of HIV-1 RNA in comparison with the other groups (Table 3). Thirty-six percent $(\mathrm{n}=34)$ of the HIV-1-infected individuals had HIV-1 RNA levels at less than 1000 copies/mL. HIV-1 RNA levels did not correlate with the levels of hepcidin $(r=0.413 ; P>0.05)$, iron $(r=0.197$; $P>0.05)$, and ferritin $(r=0.169 ; P>0.05)$. These data showed that the groups of HIV-1-infected individuals 
treated with HAART had an acceptable immune status while they were participating in the study.

\subsection{Serum Hepcidin Levels}

Serum hepcidin levels were significantly lower in the ART-naïve group compared with the NNRTI-based, PI-based and seronegative groups. However, there were no significant differences among the other groups (Table 4). In the ART-naïve group, serum hepcidin levels showed a positive correlation with the number of CD4 ${ }^{+}$T-cells $(r=0.330 ; P<0.05)$, iron $(r=0.437 ; P<0.05)$, and ferritin $(r=0.408 ; P<0.05)$. These results suggest that serum hepcidin levels are less affected in individuals possessing a higher number of $\mathrm{CD}^{+}{ }^{+} \mathrm{T}$-cells and undetectable HIV-1 RNA levels.

\subsection{Hematological Screening}

Hematological screening tests showed no occurrence of anemia in the study groups. Hemoglobin levels and erythrocyte counts showed no significant differences when compared (Table 4). Additional hematological

Table 3. Markers of infection and HIV-1 RNA levels in HIV-1-infected individuals with highly active antiretroviral therapy (HAART) regimens as well as in ART-naïve individuals, $n=372$.

\begin{tabular}{|c|c|c|c|c|}
\hline \multicolumn{5}{|c|}{ HIV-1-infected individuals $(\mathrm{n}=372)$} \\
\hline Parameters $^{(1)}$ & ART-naïve (n = 93) & NNRTI-based $(\mathrm{n}=151)$ & PI-based $(n=128)$ & $P$ value $^{(2)}$ \\
\hline $\mathrm{CD}^{+} \mathrm{T}$-cell (cells/mm³) & $374(217,483)^{*}$ & $477(353,695)$ & 497 (388, 679) & $<0.05$ \\
\hline $\mathrm{CD}^{+} \mathrm{T}$-cell (cells $/ \mathrm{mm}^{3}$ ) & $958(641,1287)$ & $940(671,1201)$ & $1.075(732,1223)$ & ns \\
\hline $\mathrm{CD}^{+}: \mathrm{CD}^{+}$ratio & $0.4(0.3,0.6)$ & $0.5(0.3,0.6)$ & $0.5(0.3,0.5)$ & ns \\
\hline HIV-1 RNA (copies/mL) $)^{(3)}$ & $98.340 \pm 96.270^{*}$ & $<50$ & $<50$ & $<0.05$ \\
\hline
\end{tabular}

Note: NNRTI, non-nucleoside reverse transcriptase inhibitor; PI, protease inhibitor; ns, no significant difference. ${ }^{(1)}$ Median [interquartile range (IQR): 25\% - 75\%; 95\% confidence interval (CI)]. ${ }^{(2)} P$ value: comparison between groups by univariate analysis of variance (ANOVA) for multiple comparisons and Tukey's honest significant difference (HSD) test. ${ }^{(3)}$ Mean values (m \pm SD). ${ }^{*} P<0.05$ when compared with other groups.

Table 4. Serum hepcidin levels and laboratorial parameters in the seronegative group, HIV-1-infected individuals with highly active antiretroviral therapy (HAART) regimens and ART-naïve individuals, $\mathrm{n}=448$.

\begin{tabular}{|c|c|c|c|c|c|}
\hline \multirow[b]{2}{*}{ Parameters $^{(1)}$} & \multicolumn{5}{|c|}{ HIV-1-infected individuals $(\mathrm{n}=372$ ) } \\
\hline & $\begin{array}{l}\text { Seronegative } \\
\quad(\mathrm{n}=76)\end{array}$ & $\begin{array}{l}\text { ART-naïve } \\
\text { (n = 93) }\end{array}$ & $\begin{array}{l}\text { NNRTI-based } \\
\quad(\mathrm{n}=151)\end{array}$ & $\begin{array}{l}\text { PI-based } \\
(\mathrm{n}=128)\end{array}$ & P value ${ }^{(2)}$ \\
\hline Hepcidin $(\mu \mathrm{g} / \mathrm{L})$ & $352 \pm 119$ & $261 \pm 137^{*}$ & $388 \pm 184$ & $406 \pm 205$ & $<0.05$ \\
\hline \multicolumn{6}{|l|}{ Hemoglobin (g/dL) } \\
\hline Male & $15.9 \pm 1.4$ & $14.3 \pm 1.9$ & $15.3 \pm 1.8$ & $16.0 \pm 1.9$ & ns \\
\hline Female & $14.4 \pm 1.3$ & $13.0 \pm 1.4$ & $14.0 \pm 1.6$ & $14.2 \pm 1.5$ & ns \\
\hline \multicolumn{6}{|l|}{ Erythrocytes (cells/mm³) } \\
\hline Male & $5.2 \pm 0.6$ & $4.5 \pm 0.5$ & $5.1 \pm 0.5$ & $5.3 \pm 0.6$ & ns \\
\hline Female & $4.6 \pm 0.3$ & $4.0 \pm 0.4$ & $4.5 \pm 0.3$ & $4.8 \pm 0.4$ & ns \\
\hline \multicolumn{6}{|l|}{ Iron biomarkers } \\
\hline Iron $(\mu \mathrm{g} / \mathrm{dL})$ & $86 \pm 18$ & $77 \pm 25^{*}$ & $88 \pm 25$ & $85 \pm 23$ & $<0.05$ \\
\hline Ferritin (ng/dL) & $212 \pm 57$ & $151 \pm 41^{*}$ & $185 \pm 54$ & $181 \pm 62$ & $<0.05$ \\
\hline Transferrin saturation (\%) & $27 \pm 4$ & $25 \pm 6$ & $27 \pm 6$ & $26 \pm 10$ & ns \\
\hline TIBC $(\mu \mathrm{g} / \mathrm{dL})$ & $306 \pm 37$ & $308 \pm 63$ & $317 \pm 49$ & $322 \pm 84$ & ns \\
\hline
\end{tabular}

Note: NNRTI, non-nucleoside reverse transcriptase inhibitor; PI, protease inhibitor; TIBC, total iron binding capacity; ns, no significant difference. ${ }^{(1)}$ Mean values $(\mathrm{m} \pm \mathrm{SD}) .{ }^{(2)} P$ value: comparison between groups by ANOVA and Tukey's honest significant difference (HSD) test. ${ }^{*} P<0.05$ when compared with other groups. 
parameters did not show significant changes as characterized by anemia (data not shown). These data suggest that even in the ART-naïve group, HIV-1 infection associated with a reduction inCD4 ${ }^{+}$T-cells did not alter the physiology and morphology of erythrocytes.

\subsection{Iron-Based Biomarkers}

Serum iron and ferritin levels were significantly different only in the ART-naïve group, which showed lower values compared with the NNRTI-based, PI-based and seronegative groups. The values for transferrin saturation and TIBC showed no significant differences between groups (Table 4). The results suggest that in the ARTnaïve group, HIV-1 infection affects serum iron levels and its deposition.

\section{Discussion}

We demonstrated that serum hepcidin levels, as well as iron and ferritin, were reduced in the ART-naïve group and showed a positive correlation with the number of $\mathrm{CD}^{+}$T-cells, but not with HIV-1 RNA levels. In the groups receiving different HAART regimens, these same parameters were within the normal range and/or represented values that are considered indicators of immune recovery, suggesting that immune status in HIV-1infected individuals may directly affect serum hepcidin levels and iron metabolism.

In this study, HIV-1-infected individuals who received different regimens of HAART had undetectable HIV-1 RNA levels, and the number of $\mathrm{CD}^{+}$T-cells was within the normal range, while the ART-naïve group had reduced levels of HIV-1 RNA and CD4 ${ }^{+}$T-cells. HIV-1 RNA levels and CD4 ${ }^{+}$T-cell numbers are indicators of the clinical stage of infection and are considered prognostic factors for the evaluation of the course of HIV-1 infection [16] [17]. The maintenance of $\mathrm{CD}^{+} \mathrm{T}$-cell and $\mathrm{CD}^{+} \mathrm{T}$-cell numbers characterizes the efficacy of HAART, which inhibits viral replication, slows the progression of immunodeficiency, and therefore restores immunity and increases the quality of life for HIV-1-infected individuals [18] [19]. Therefore, it is possible to infer a relationship between the number of CD4 ${ }^{+} \mathrm{T}$-cells and serum hepcidin levels, which would be directly related to the best course of HIV-1 infection.

The observed positive correlation between serum hepcidin levels and CD4 ${ }^{+}$T-cells in the ART-naive group, but not in the groups receiving HAART, is different than the results obtained by Wisaksana and colleagues (2013) [20], who conducted studies on Indonesian individuals infected with HIV and tuberculosis (TB) concomitantly. These authors showed that serum hepcidin levels exhibited an inverse correlation with levels of CD4 ${ }^{+}$ T-cells. However, they emphasized that in the HIV-infected individuals without TB and with CD4 ${ }^{+}$T-cell counts above 200 cells $/ \mathrm{mm}^{3}$, serum hepcidin levels were similar to those in healthy adults, which confirms the results obtained in our study. In turn, studies carried out by Boelaert and colleagues (2007) [21] and Sow and colleagues (2007) [22] also showed elevated levels of hepcidin in individuals infected with M. tuberculosis, and they suggested that components of the mycobacterium could be contributing to increased serum hepcidin levels. As described above, the HIV-1-infected individuals in our study received prior laboratory evaluation for periods of ninety days and had no other co-morbidities such as tuberculosis and/or hepatitis that could affect iron metabolism and/or present advanced infection by HIV-1. Even the individuals in the ART-naïve group had no advanced infection nora clinical status that was suggestive of AIDS.

In HIV-1 infection, in addition to macrophages and CD4 ${ }^{+}$T-cells, there is a direct infection of progenitor cells in the bone marrow, which in turn can induce bone marrow suppression with a consequent increase in hepcidin expression, especially upon high concentrations of viral replication common in acute or advanced HIV-1 infection [23] [24]. However, we should be cognizant that even in individuals with undetectable HIV-1 RNA in our groups with different HAART regimens, there is still residual viral replication because the virus is not completely eradicated [25] [26]. These residual virus particles in subjects receiving HAART persist in macrophages and resting memory CD4 ${ }^{+}$T-cells and are considered reservoirs of HIV-1 [27] [28]. Thus, it has been shown that

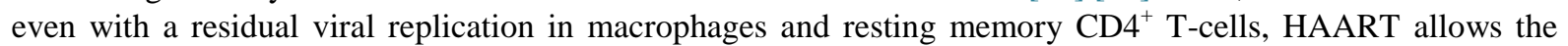
quantitative and qualitative restoration of the total pool of $\mathrm{CD} 4{ }^{+} \mathrm{T}$-cells, which restores the immune system, and therefore reduces the impact on the bone marrow progenitor cells [29] [30]. The end result would be a minor impact on the expression of hepcidin and on iron and ferritin levels, as observed in our groups treated with different HAART regimens.

The possibility that HAART affects the metabolism of iron and, consequently, hepcidin levels, can alsobe considered because this effect has been documented, for example, with zidovudine (AZT)-induced suppression 
of bone marrow [31]. However, this hypothesis does not take into account the reduced levels of hepcidin, iron and ferritin observed in our ART-naïve group because those groups with different HAART regimens containing AZT did not display changes in the levels of these parameters, nor did these groups have any type of anemia or changes in iron metabolism. We can with some degree of certainty consider that modern HAART treatment can considerably overcome many of these effects [17] [19] [32].

In acute and/or advanced infectious processes, inflammation is known to be an aggravating factor in iron metabolism because iron [6] overload may occur, which is accompanied by an increase in levels of hepcidin and a subsequent decrease in the intestinal absorption of iron and release of iron depositsviairon degradation [6] [7]. Conversely, iron deficiency, hypoxia and enhanced erythropoiesis contribute to decreased hepcidin levels [33]. The changes in serum hepcidin levels only occurred in individuals in the ART-naïve group, even those without clinical signs of anemia, bone marrow suppression, or diagnosis of co-morbidities. Thus, the immune status of the groups was restored with different HAART regimens, as characterized by undetectable HIV-1 RNA levels and a sufficient number of CD4+ T-cells, confirming our hypothesis that maintenance of the immune system can revert the decline in hepcidin levels, and without advanced HIV-1 infection, critical conditions that could produce major changes in the levels of hepcidin were not observed.

Previous studies on the relationship between iron status and hepcidin levels showed a positive association between hepcidin and serum ferritin and iron levels [34] [35]. These studies support the results obtained in our study, where low levels of iron and ferritin observed in the ART-naïve group showed a direct relationship with the reduction in the levels of hepcidin. In this context, hepcidin is the main regulator of iron metabolism and is also an acute phase protein induced by cytokines during infection and inflammation [2] [11], especially in cases of acute infection with continuous viral replication of HIV-1; thus, this partially explains the direct relationship with the levels of iron and ferritin [6] [10] [12].

It is important to consider that the survival of individuals who are seropositive for HIV-1 is accompanied by a chronic infectious process and continuous treatments with side effects, exposing these individuals to a number of complex situations that are multifactorial and interrelated, including changes in iron metabolism [14] [32] [36]. One limitation of the present study is that it is cross-sectional. Thus, although a longitudinal clinical trial was performed with these HIV-1-infected individuals, a temporal analysis was not possible. However, this study established that the factor that likely causes the reduction inserum hepcidin levels was suppression of the immune system by HIV-1.

\section{Conclusion}

Our results showed that reduced levels of hepcidin, iron and ferritin were associated with a reduction in the number of $\mathrm{CD} 4^{+} \mathrm{T}$-cells in HIV-1-infected individuals with no treatment. In the groups receiving different regimens of HAART, which exhibited a restored immune system as characterized by the recovery of $\mathrm{CD} 4^{+} \mathrm{T}$-cells and undetectable levels of HIV-1 RNA, the same parameters were within the normal range. These results suggest that HIV-1 infection affects the levels of serum hepcidin, the main regulator of iron metabolism, with subsequent changes in iron levels in the circulation and within deposits. Moreover, different HAART regimens can adequately reverse this condition.

\section{Acknowledgements}

The authors would like to thank Professor Manoel Rosa de Oliveira Lino ( $\mathrm{PhD}$ ) from the Department of Informatics and Statistics at the Federal University of Santa Catarina for his contributions to the statistical analyses. This study was financially supported by resources from The National Council for Scientific and Technological Development (CNPq), the State of São Paulo Research Foundation (FAPESP), and the National Institute of Science and Technology of Complex Fluids (INCT-FCx).

\section{Conflict of Interests}

The authors state that there are no conflicts of interest regarding the publication of this paper.

\section{References}

[1] Ganz, T. (2007) Molecular Control Iron Transport. Journal of the American Society of Nephrology, 18, 394-400. 
http://dx.doi.org/10.1681/ASN.2006070802

[2] Coyne, D.W. (2011) Hepcidin: Clinical Utility as a Diagnostic Tool and Therapeutic Target. Kidney International, 80, 240-244. http://dx.doi.org/10.1038/ki.2011.141

[3] Babitt, J.L. and Lin, H.Y. (2010) Molecular Mechanisms of Hepcidin Regulation: Implications for the Anemia of CKD. American Journal of Kidney Diseases, 55, 726-741. http://dx.doi.org/10.1053/j.ajkd.2009.12.030

[4] Roy, C.N., Mak, H.H., Akpan, I., Losyev, G., Zurakowski, D. and Andrews, N.C. (2007) Hepcidin Antimicrobial Peptide Transgenicmice Exhibit Features of the Anemia of Inflammation. Blood, 109, 4038-4044. http://dx.doi.org/10.1182/blood-2006-10-051755

[5] Nemeth, E., Rivera, S., Gabayan, V., Keller, C., Taudorf, S., Pedersen, B.K. and Ganz, T. (2004) IL-6 Mediates Hypoferremia of Inflammation by Inducing the Synthesis of the Iron Regulatory Hormone Hepcidin. The Journal of Clinical Investigation, 113, 1271-1276. http://dx.doi.org/10.1172/JCI200420945

[6] Donovan, A., Lima, C.A., Pinkus, J.L., Zon, L.I., Robine, S. and Andrews, N.C. (2005) The Iron Exporter Ferroportin/Slc40a1 Is Essential for Iron Homeostasis. Cell Metabolism, 1, 191-200. http://dx.doi.org/10.1016/j.cmet.2005.01.003

[7] Nemeth, E. and Ganz, T. (2006) Regulation of Iron Metabolism by Hepcidin. Annual Review of Nutrition, 26, $323-342$. http://dx.doi.org/10.1146/annurev.nutr.26.061505.111303

[8] Ford, B.A., Eby, C.S., Scott, M.G. and Coyne, D.W. (2010) Intra-Individual Variability in Serum Hepcidin Precludes Its Use as a Marker of Iron Status in Hemodialysis Patients. Kidney International, 78, 769-773. http://dx.doi.org/10.1038/ki.2010.254

[9] Coyne, D. (2006) Iron Indices: What Do They Really Mean? Kidney International, 69, S4-S8. http://dx.doi.org/10.1038/sj.ki.5000404

[10] Lee, P., Peng, H., Gelbart, T., Wang, L. and Beutler, E. (2005) Regulation of Hepcidin Transcription by Interleukin-1 and Interleukin-6. Proceedings of the National Academy of Sciences of the United States of America, 102, 1906-1910. http://dx.doi.org/10.1073/pnas.0409808102

[11] Ganz, T. (2002) The Role of Hepcidin in Iron Sequestration during Infections and in the Pathogenesis of Anemia of Chronic Disease. Israel Medical Association Journal, 4, 1043-1045.

[12] McDermid, J.M., Jaye, A., Schim van der Loeff, M.F., Todd, J., Bates, C., Austin, S., Jeffries, D., Awasana, A.A., Whitlex, A.A. and Prentice, A. (2007) Elevated Iron Status Strongly Predicts Mortality in West African Adults with HIV Infection. Journal of Acquired Immune Deficiency Syndromes, 46, 498-507. http://dx.doi.org/10.1097/QAI.0b013e31815b2d4b

[13] Xu, M., Kashanchi, F., Foster, A., Rotimi, J., Turner, W., Gordeuk, V.R. and Nekhai, S. (2010) Hepcidin Induces HIV-1 Transcription Inhibited by Ferroportin. Retrovirology, 7, 104. http://dx.doi.org/10.1186/1742-4690-7-104

[14] Gordeuk, V.R., Delanghe, J.R., Langlois, M.R. and Boelaert, J.R. (2001) Iron Status and the Outcome of HIV Infection: An Overview. Journal of Clinical Virology, 20, 111-115. http://dx.doi.org/10.1016/s1386-6532(00)00134-7

[15] Rawat, R., Humphrey, J.H., Ntozini, R., Mutasa, K., Iliff, P.J. and Stoltzfus, R.J. (2009) Elevated Iron Stores Are Associated with HIV Disease Severity and Mortality among Postpartum Women in Zimbabwe. Public Health Nutrition, 12, 1321-1329. http://dx.doi.org/10.1017/S136898000800390X

[16] Dubé, M.P., Lipshultz, S.E., Fichtenbaum, C.J., Greenberg, R., Schecter, A.D. and Fisher, S.D. (2008) Effects of HIV Infection and Antiretroviral Therapy on the Heart and Vasculature. Circulation, 118, e36-e40. http://dx.doi.org/10.1161/CIRCULATIONAHA.107.189625

[17] da Cunha, J., Ferreira Maselli, L.M., Treitinger, A., Monteiro, A.M., Gidlund, M., Maranhão, R.C., Spada, C. and Bydlowski, S.P. (2013) Serum Levels of IgG Antibodies against Oxidized LDL and Atherogenic Indices in HIV-1-Infected Patients Treated with Protease Inhibitors. Clinical Chemistry and Laboratory Medicine, 51, 371-378. http://dx.doi.org/10.1515/cclm-2012-0225

[18] Savès, M., Morlat, P., Chêne, G., Peuchant, E., Pellegrin, I., Bonnet, F., Bernard, N., Lacoste, D., Salamon, R. and Beylot, J. (2001) Prognostic Value of Plasma Markers of Immune Activation in Patients with Advanced HIV Disease Treated by Combination Antiretroviral Therapy. Clinical Immunology, 99, 347-352. http://dx.doi.org/10.1006/clim.2001.5033

[19] Maselli, L.M.F., da Cunha, J., Gutierrez, E.B., Maranhão, R.C., Spada, C. and Bydlowski, S.P. (2014) Human Paraoxonase-1 Activity Is Related to the Number of CD4+ T-Cells and Is Restored by Antiretroviral Therapy in HIV-1-Infected Individuals. Disease Markers, 2014, Article ID: 480201.

[20] Wisaksana, R., de Mast, Q., Alisjahbana, B., Jusuf, H., Sudjana, P., Indrati, A.R., Sumantri, R. Swinkels, D., van Crevel, R. and van der Ven, A. (2013) Inverse Relationship of Serum Hepcidin Levels with CD4 Cell Counts in HIVInfected Patients Selected from an Indonesian Prospective Cohort Study. PLoS ONE, 8, e79904.

http://dx.doi.org/10.1371/journal.pone.0079904 
[21] Boelaert, J.R., Vandecasteele, S.J., Appelberg, R. and Gordeuk, V.R. (2007) The Effect of the Host's Iron Status on Tuberculosis. The Journal of Infectious Diseases, 195, 1745-1753. http://dx.doi.org/10.1086/518040

[22] Sow, F.B., Florence, W.C., Satoskar, A.R., Schlesinger, L.S., Zwilling, B.S. and Lafuse, W.P. (2007) Expression and Localization of Hepcidin in Macrophages: A Role in Host Defense against Tuberculosis. Journal of Leukocyte Biology, 82, 934-945. http://dx.doi.org/10.1189/jlb.0407216

[23] Kanda, J., Mizumoto, C., Kawabata, H., Tsuchida, H., Tomosugi, N., Matsuo, K. and Uchiyama, T. (2008) Serum Hepcidin Level and Erythropoietic Activity after Hematopoietic Stem Cell Transplantation. Haematologica, 93, 15501554. http://dx.doi.org/10.3324/haematol.12399

[24] Pak, M., Lopez, M.A., Gabayan, V., Ganz, T. and Rivera, S. (2006) Suppression of Hepcidin during Anemia Requires Erythropoietic Activity. Blood, 108, 3730-3735. http://dx.doi.org/10.1182/blood-2006-06-028787

[25] Maldarelli, F., Palmer, S., King, M.S., Wiegand, A., Polis, M.A., Mican, J., Kovacs, J.A., Davey, R.T., Rock-Kress, D., Dewar, R., Liu, S., Metcalf, J.A., Rehm, C., Brun, S.C., Hanna, G.J., Kempf, D.J., Coffin, J.M. and Mellors, J.W. (2007) ART Suppresses Plasma HIV-1 RNA to a Stable Set Point Predicted by Pretherapy Viremia. PLoS Pathogens, 3, e46. http://dx.doi.org/10.1371/journal.ppat.0030046

[26] Deere, J.D., Kauffman, R.C., Cannavo, E., Higgins, J., Villalobos, A., Adamson, L., Schinazi, R.F., Luciw, P.A. and North, T.W. (2014) Analysis of Multiply Spliced Transcripts in Lymphoid Tissue Reservoirs of Rhesus Macaques Infected with RT-SHIV during HAART. PLOS ONE, 9, e87914. http://dx.doi.org/10.1371/journal.pone.0087914

[27] Finzi, D., Blankson, J., Siliciano, J.D., Margolick, J.B., Chadwick, K., Pierson, T., Smith, K., Lisziewicz, J., Lori, F., Flexner, C., Quinn, T.C., Chaisson, R.E., Rosenberg, E., Walker, B., Gange, S., Gallant, J. and Siliciano, R.F. (1999) Latent Infection of $\mathrm{CD}^{+} \mathrm{T}$ Cells Provides a Mechanism for Lifelong Persistence of HIV-1, even in Patients on Effective Combination Therapy. Nature Medicine, 5, 512-517. http://dx.doi.org/10.1038/8394

[28] Chun, T.W., Engel, D., Berrey, M.M., Shea, T., Corey, L. and Fauci, A.S. (1998) Early Establishment of a Pool of Latently Infected, Resting CD4 ${ }^{+} \mathrm{T}$ Cells during Primary HIV-1 Infection. Proceedings of the National Academy of Sciences of the United States of America, 95, 8869-8873. http://dx.doi.org/10.1073/pnas.95.15.8869

[29] Lassen, K., Han, Y., Zhou, Y., Siliciano, J. and Siliciano, R.F. (2004) The Multifactorial Nature of HIV-1 Latency. Trends in Molecular Medicine, 10, 525-531. http://dx.doi.org/10.1016/j.molmed.2004.09.006

[30] Chun, T.W., Carruth, L., Finzi, D., Shen, X., DiGiuseppe, J.A., Taylor, H., Hermankova, M., Chadwick, K., Margolick, J., Quinn, T.C., Kuo, Y.H., Brookmeyer, R., Zeiger, M.A., Barditch-Crovo, P. and Siliciano, R.F. (1997) Quantification of Latent Tissue Reservoirs and Total Body Viral Load in HIV-1 Infection. Nature, 387, 183-188. http://dx.doi.org/10.1038/387183a0

[31] Aweeka, F.T., Mak, M., Al-Uzri, A., Peter, K., Dett, C., Franco, J., Affrime, M., Guerciolini, R., Cutler, D.L., Kahn, J. and Gambertoglio, J.G. (1995) Oral and Intravenous Zidovudine Pharmacokinetics: The Effect of Granulocyte-Macrophage Colony Stimulating Factor. The Journal of Clinical Pharmacology, 35, 856-864. http://dx.doi.org/10.1002/j.1552-4604.1995.tb04130.x

[32] Hill, A. and Sawyer, W. (2009) Effects of Nucleoside Reverse Transcriptase Inhibitor Backbone on the Efficacy of First-Line Boosted Highly Active Antiretroviral Therapy Based on Protease Inhibitors: Meta-Regression Analysis of 12 Clinical Trials In 5168 Patients. HIV Medicine, 10, 527-535. http://dx.doi.org/10.1111/j.1468-1293.2009.00724.x

[33] Fleming, R.E. and Ponka, P. (2012) Iron Overload in Human Disease. New England Journal of Medicine, 366, $348-359$. http://dx.doi.org/10.1056/NEJMra1004967

[34] Hentze, M.W., Muckenthaler, M.U., Galy, B. and Camaschella, C. (2010) Two to Tango: Regulation of Mammalian Iron Metabolism. Cell, 142, 24-38. http://dx.doi.org/10.1016/j.cell.2010.06.028

[35] Ramos, E., Kautz, L., Rodriguez, R., Hansen, M., Gabayan, V., Ginzburg, Y., Roth, M.P., Nemeth, E. and Ganz, T. (2011) Evidence for Distinct Pathways of Hepcidin Regulation by Acute and Chronic Iron Loading in Mice. Hepatology, 53, 1333-1341. http://dx.doi.org/10.1002/hep.24178

[36] May, M., Sterne, J.A., Sabin, C., Costagliola, D., Justice, A.C., Thiébaut, R., Gill, J., Phillips, A., Reiss, P., Hogg, R., Ledergerber, B., D’Arminio Monforte, A., Schmeisser, N., Staszewski, S. and Egger, M. (2007) Prognosis of HIV-1Infected Patients up to 5 Years after Initiation of HAART: Collaborative Analysis of Prospective Studies. AIDS, 21, 1185-1197. http://dx.doi.org/10.1097/QAD.0b013e328133f285 


\section{List of Abbreviations}

HIV-1: Human immunodeficiency virus type1

HAART: Highly active antiretroviral therapy

NNRTI: Non-nucleoside reverse transcriptase inhibitor

NRTI: Nucleoside reverse transcriptase inhibitor

PI: Protease inhibitors

ANOVA: Analysis of variance (univariate variance for multiple comparisons)

TIBC: Total iron binding capacity 